IRA-International Journal of Management \& Social Sciences

ISSN 2455-2267; Vol.08, Issue 02 (August 2017)

Pg. no. 175-187

Institute of Research Advances

http://research-advances.org/index.php/RAJMSS

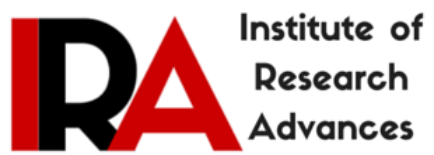

\title{
The Family Business as a Driver of the Social Economy: The Case of a Tourist Cooperative in Sinaloa, Mexico
}

\author{
Alvarado-Borrego A. ${ }^{1}$, Ibarra-Michel J. P. ${ }^{2}$, Soto-Karass J. G. ${ }^{3}$ \\ ${ }^{1}$ Research Scholar, Department of Administrative Sciences, Universidad de Occidente. Los Mochis Sinaloa, México. \\ ${ }^{2}$ Research Scholar, Department of Social Sciences and Humanities, University of Occidente. Mazatlán Sinaloa, México. \\ ${ }^{3}$ Professor, Department of Administrative Sciences, Universidad de Occidente. Los Mochis Sinaloa, México.
}

Type of Review: Peer Reviewed.

DOI: http://dx.doi.org/10.21013/jmss.v8.n2.p5

How to cite this paper:

Alvarado-Borrego A. A., Ibarra-Michel J. P., Soto-Karass J. G. (2017). The Family Business as a Driver of the Social Economy: The Case of a Tourist Cooperative in Sinaloa, Mexico. IRA-International Journal of Management \& Social Sciences (ISSN 2455-2267), 8(2), 175-187. doi:http://dx.doi.org/10.21013/jmss.v8.n2.p5

(C) Institute of Research Advances.

\section{(cc)) BY-NO}

This work is licensed under a Creative Commons Attribution-Non Commercial 4.0 International License subject to proper citation to the publication source of the work.

Disclaimer: The scholarly papers as reviewed and published by the Institute of Research Advances (IRA) are the views and opinions of their respective authors and are not the views or opinions of the IRA. The IRA disclaims of any harm or loss caused due to the published content to any party.

Institute of Research Advances is an institutional publisher member of Publishers Inter Linking Association Inc. (PILA-CrossRef), USA. The institute is an institutional signatory to the Budapest Open Access Initiative, Hungary advocating the open access of scientific and scholarly knowledge. The Institute is a registered content provider under Open Access Initiative Protocol for Metadata Harvesting (OAI-PMH).

The journal is indexed \& included in WorldCat Discovery Service (USA), CrossRef Metadata Search (USA), WorldCat (USA), OCLC (USA), Open J-Gate (India), EZB (Germany) Scilit (Switzerland), Airiti (China), Bielefeld Academic Search Engine (BASE) of Bielefeld University, Germany, PKP Index of Simon Fraser University, Canada. 


\begin{abstract}
The family business in the field of social economy represents the actions and commitments it has with its members and the community, according to the philosophy and principles of the cooperative as a business organization; it also helps to strengthen its social capital and promote family integration.The objective of the study was to analyze the family business as a boost to the social economy from the organizational figure of the cooperative, taking as a case study a tourist cooperative in northern Sinaloa, Mexico. This business has more than 30 years' operating as a cooperative society and is in its third generation, is made up of 15 members, members of the same family who in turn hold the main positions at the general assembly. The research was conducted as a case studywith a qualitative methodology approach, collecting data through observation, review of documents and semi-structured interviews to key family members. The results indicate that the family and cooperative business, share decision-making and collective well-being, promoting the social economy by working together and distributing goods fairly; allowing the continuity of the company for the next generation.
\end{abstract}

Key words: Family business, Social economy and Cooperative society.

\title{
Introduction
}

The studies of family businesses are important, transcendent and increasingly necessary, whether they are about the analysis of succession, conflict, power, leadership, communication or innovation; among the reasons for this, just to mention one aspect, there are some consanguine actors that have a continuous participation in the construction of their knowledge that are shared from generation to generation.

These family businesses also maintain a direct relationship with the environment around them, in such a way that they extend their scope of action, since as a family, they belong to the type of social organization where their interest is to strengthen links for the benefit of the community or society in which they are. Puga (2006), cited by Meira and Carvalhal (2013), states that family businesses are directly responsible for social development, generating opportunities for inclusion in society through the creation of approximately $75 \%$ of new jobs and maintenance of $85 \%$ of existing jobs.

In this sense, the social development aimed at the better living conditions of the inhabitants, finds an echo in the social economy in terms of commitment, will and solidarity as an alternative that contributes to the solution of various problems facing by the community and the family businesses.For this reason, the present research, with a case study approach, analyzes the participation of this kind of entrepreneurship in the promotion and improvement of the social economy specifically in the figure of a cooperative as form of business organization.However, in this particular case, there are some unsolved issues of the members of the cooperative and the family itself that limit its development and put this family business with 35 years of service in the northwest of Sinaloa in a fragile situation.

\section{Methodology.}

The case study is a research strategy that allowed us to have an approach to the Cooperative Society of Tourist Services Beaches "El Maviri", located in the northwest of Sinaloa, Mexico, in order to analyze the family business as a boost to the social economy. The research was carried out with a qualitative approach, with data collection through observation of the practices performed by the family to offer services such as management and organization to provide services to the tourist, reviewed documents such as requests and permits to operate, historical documents of the family, and others, as well as semi-structured interviews with key family members, including the former legal representative of the cooperative and his son.

\section{Literature review}

\section{Family business}

All social organization, which is transformed into an economic unit, at the beginning or at some other stage of its life, had to be of a family nature. This kind of company, forms the reality that manifests, in a clear way, in the daily life of our country. 
According to Gómez-Betancourt (2005: 23), in the market economy, the entrepreneur is the key. If there are no entrepreneurs, there is no company, no job creation, no wealth. The same author continued by saying that within the group of companies, family business, are the backbone of economic development. Likewise, Neubauer and Lank (2003: 28) point out that we have to keep them healthy and well governed (family businesses), since the welfare of our society depends to a great extent on them. For KMPG ${ }^{1}$ Mexico (2013) these organizations, mostly arise with the purpose of generating sources of work and heritage; however, they need to secure themselves to ensure their survival.

A family business, according to Gallo (1995, quoted by Casillas, Rus, Díaz and Vázquez, 2014) have three characteristics:

a) The ownership or control over the company.

b) The power that the family exerts on the company, usually by the work carried out in the company by some of the members of the family.

c) The intention to transfer the company to future generations and its incorporation of members of this new generation in the company itself.

On the other hand, Geneva (1997), indicates that the character of family business is determined by the following factors:

a) The group are only parents and children; that is, it extends to two physical generations. There may be grandchildren of the founder, but without relevance or, what is the same, with the entire command of the generation of brothers.

b) The real stock control has the family.

c) The family is the group that directs.

d) The family assets committed in the company account for at least $25 \%$ of total family assets.

Also, Leach (1999) considers this type of company as those that are influenced by a family or by a family bond. In the most obvious case, the family as an entity can effectively control the operations of the company because it owns more than 50 percent of the shares, or because members of the family occupy important positions in management. But in addition to these situations, one should not overlook those less obvious cases, where the firm's operations are affected by the family bond, companies in which the parent-child-brother-sister relationship, in-laws and cousins have a significant impact on the future of the organization.

Each of the aspects of the conceptions described above is included in three elements that, for Neubauer and Lank (1999, cited by Casillas, Rus, Diaz and Vázquez, 2014), make up the defining areas of the family business:

- Ownership and control (percentage of ownership in the family owned, family control over the company);

- The direction (family performance of the executive functions of the company), and

- Continuity (Intention to maintain in the future the participation of the family in the company, the number of generations of the family that owns the family or the fact that the direct descendants of the founder have control over the management or over the ownership of the company).

\section{Types of family businesses}

The family business community is different from each other,with similar peculiarities in certain factors, however, they have very unequal properties in other aspects. On the other hand, the criteria by which a classification of family businesses can be formed are different. In Table 1, according to Casillas, et al (2014: 18-23), the types of family businesses are shown according to several criteria:

\footnotetext{
${ }^{1}$ Klynveld, Peat, Marwick \& Goerdeler Co.
} 
Table 1. Types of family businesses

Depending on

\section{Demographic criteria}

Generational Degree

Consists

Contemplates

Size: There are large, medium and small family businesses.

Geographical scope: There are local,

The family business can be classified on the basis of these criteria precisely because the company can not be identified with any of the types of company that can be described in relation to these criteria.

This factor is linked to the generational level that the company lives. The generational level is necessarily related to the organizational age and this, in turn, is usually intimately linked to the different evolutionary phases through which any company (life cycle) goes through. Likewise, the generation level influences the number of owners and the relationships between them. regional, national and multinational
family

Type of property and its legal form: There are family companies that are companies and others that do not, and of the former, there are limited liability companies, corporations and other types: some are not publicly traded and others are.

Companies in first generation (founder): They are companies in which the founder controls the company. For many authors, this type of business can only be considered as a family business if any member of the next generation (children, nephews, etc.) is already incorporated in the company performing some type of function.

In this first generational level, the property may be unique or may be shared, either with other members of the family or outside of it (non-family partners). Likewise, an essential figure in this type of company is constituted by the spouse of the founder or founder, whose behavior and attitude will have great relevance for the generational continuity.

Companies in second generation (brothers company): These are companies in which the founder, in case of living, has passed into the background and effective control falls on his children or nephews. The property is usually in the hands of several brothers. Management control, however, can be either in the hands of the family or in the hands of external professionals (a professionalized family business) or even can be shared between family and external members. In the event that siblings take part in management, they all can do it or only some of them, although the most common case is that one of them holds the most responsibility of the company and it's the one who monopolizes the family leadership in the company.

Companies in third generation and following generations (federation of cousins): These are companies in which the grandchildren, (great-grandchildren, and so on) of the founder are the main owners and managers of the familiar company. In this type of company, the complexity that exists requires 


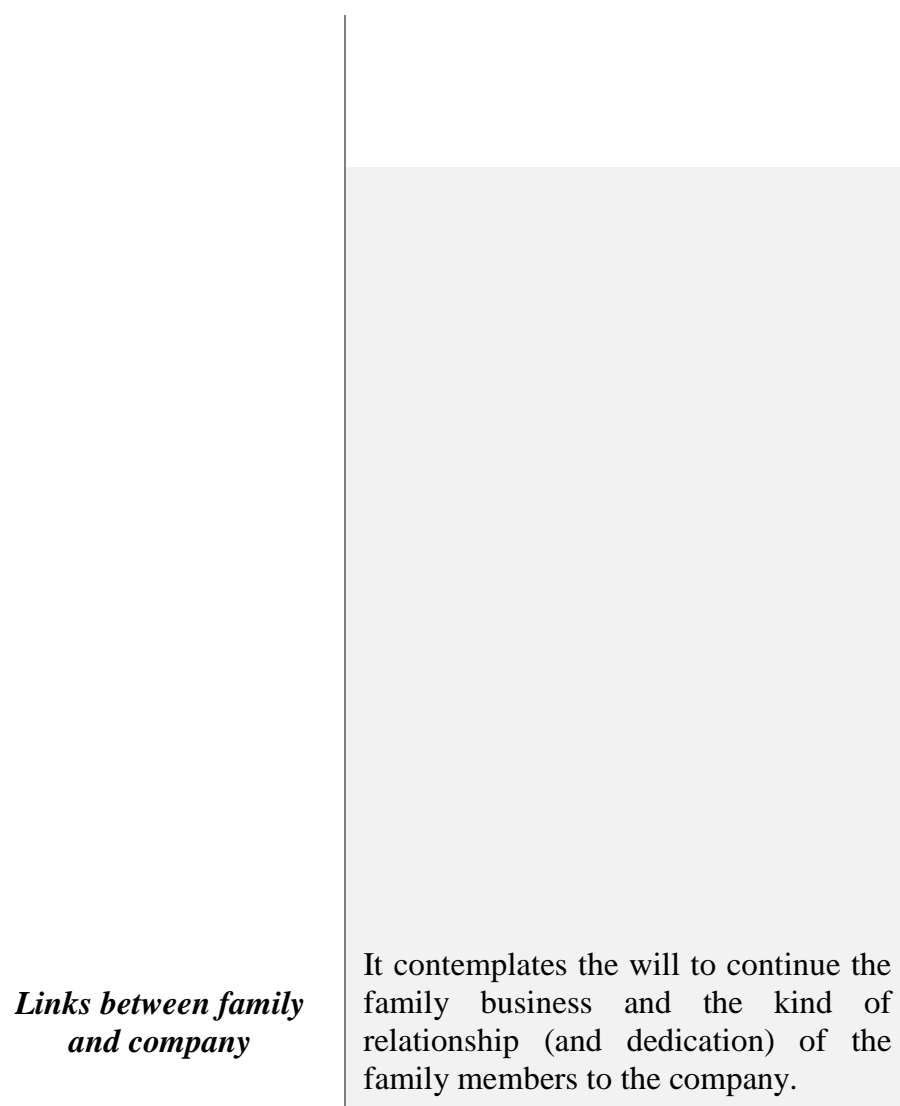

establishing formal systems of relations between the company and the family (structured governance bodies, family protocols, etc.).

Family Worker Company $(\boldsymbol{F W C})$ : it is the company whose members intend to keep the company in the hands of the family with the aim that most of the members of this family work in it, if they are willing to. In this type of companies, it is promoted that the children work in the company of the father, and thus, generation after generation, although without curtailing the will of these descendants.

Family management company (FMC): these are companies in which family members agree to keep property in the hands of the company, reserving the management and management of the company to those family members with greater skills and training. In this case, therefore, only some of the family members really have the right to work in the company and to occupy positions of responsibility in it. The rest remains linked to the company in its role of passive shareholders.

The Family Investment Firm (FIF): The members of the family are exclusively dedicated to controlling investment and divestment decisions in different businesses and not their management. The goal is to maintain the greatest freedom of action, without forcing too close a family bonding to a particular business. The aim is to maximize the profitability that the members of the family of the businesses in which it participates can obtain.

Short-term family business (STFB): these are companies in which there is no clear intention on the part of the company to maintain neither ownership nor management in the future. The existing linkage is derived from historical circumstances (inherited business or inheritance). In the future, these types of companies tend to fall apart when they receive offers from outside investors.

Source: Own elaboration (2017), based on Casillas, et al (2014).

Family businesses, like any other non-family economic unit, face great difficulties in adapting more competitive means; This phenomenon is usually reflected in its inability to keep the company in the next generation (see Figure 1). In this sense, it should be mentioned that not all family businesses disappear because of business failure. There are companies that choose to end their family character by incorporating other shareholders and diminishing their control over the direction of the company; other cause is the acceptance of cost-effective treatment by family members and the subsequent sale of the organization to third parties (Belausteguigoitia, 2012). 
Figure 1. Percentage of success in family business succession

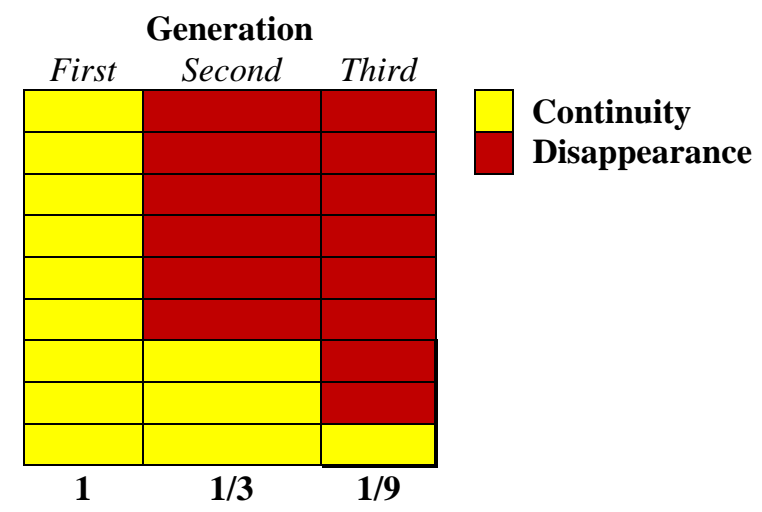

Source: Belausteguigoitia (2012), based on Lea (1993), Handler \&Kram (1998), and Costa (1994).

For Maza and Paez (1997, quoted by Belausteguigoitia, 2012), in a study conducted in micro and small Mexican companies concluded that administrative factors are the main cause of the disappearance of family businesses, followed by elements of financial order and fiscal policy.

Among the administrative subfactors that affected the extinction of these economic units, the first is the lack of an administrative system; Another factor is the operation with inadequate management systems; The third is the inefficient management of resources; The fourth and last, the lack of control (Maza and Paez, 1997, cited by Belausteguigoitia, 2012: 24-25).

\section{The family businesses in México}

In 2013, KPMG's global network of professional services firms based in Mexico conducted a study in our country on the current status of family businesses in various economic sectors; as a result of this investigative work, they obtained an interesting database that represents a diagnosis of the current situation of this kind of company. For practical purposes, Table 2 shows the concentrate of such report.

Table 2. Current national situation of family businesses.
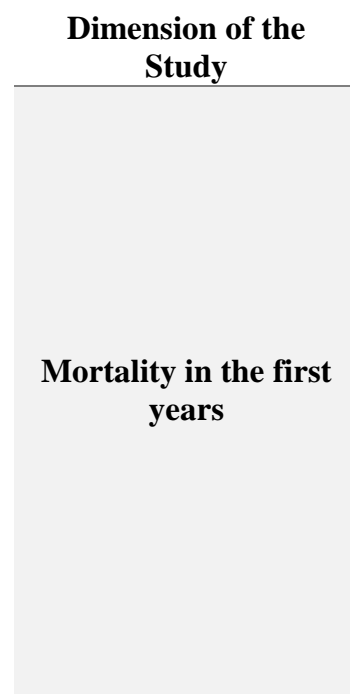

The path of institutionalization
- In Mexico, about $70 \%$ of new businesses do not reach the third year of life. - An estimated estimate, generally accepted, is that the average life expectancy of a family business is 25 years, while those managed institutionally live on average 50 years.

- $42 \%$ of the sample represents the 1 st generation; $43 \%$, the 2 nd generation; $9 \%$, the third generation, and only $6 \%$ of the family companies corresponded to the 4 th generation.

- The survey shows this trend, with $56 \%$ of companies hiring up to four partners or family members; Very few (18\%) have a lone owner; And $26 \%$ recruit more than four and up to ten consanguine.

- $94 \%$ of respondents admit that incorporating family members is complicated and even very difficult, because hiring is usually done on an emotional rather than strategic basis.

- Only in a few cases ( $16 \%$ of the answers) do the family members seem to comply with the idea of disciplined integration and shared goals, as well as the built culture of the company

- Only $13 \%$ of the respondents considered a succession process, which should not only refer to the possible death of a partner, but also to changes in direction, voluntary retirement and passing of the courier to those who come after.

- It is noteworthy that more than half of the respondents $(55 \%)$ are not aware or prepared and do not have a succession plan, while $32 \%$ admit partial measures on that issue. 


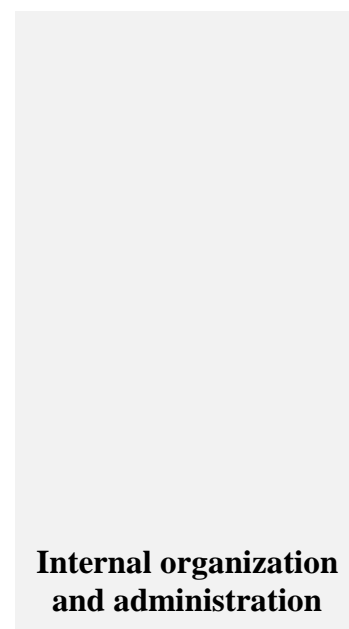

- Of the $13 \%$ of companies that have a succession plan, only $20 \%$ agree that they have clarity about the procedure. In contrast, $80 \%$ admit partial or unclear scenarios, suggesting a more or less inevitable conflict.

- One of the signs of functional weakness of family businesses is the lack of operation of the driving body, such as the Board of Directors, which only $45 \%$ of the respondents have established; In the remaining group, it must be understood that the function is occupied by the so-called single administrator. - In cases where there is a Board of Directors, only $27 \%$ appear to fulfill the purpose of discussing, negotiating and making plans. The rest of the responses suggest that it is a merely informal, perhaps sporadic, meeting for accounting purposes and to meet administrative requirements.

- Another significant fact is that only $30 \%$ of the councils include in their meetings independent directors, a component that does not represent a significant cost, and has the function of providing an external vision.

- Only $12 \%$ of the companies interviewed, among which there are some with more than 300 and 500 workers, have a Corporate Governance manual. - $65 \%$ of firms also lack an Audit Committee, which is an essential part of Corporate Governance, and can be understood as an instance of comprehensive risk control and management.

- In the small proportion of companies that do have a Committee (35\% of the total), only $17 \%$ is chaired by an independent agent, responsible for determining whether things are fine or if there are deviations in administration, treasury, adverse events and their effects on the company or on tax commitments, etc. In the rest, it is understood that the owner will be one of the partners or directors and it will be perhaps the same person in charge of doing those same tasks that must be supervised.

- $32 \%$ of the respondents recognize possible resistance to organize the company in a more institutional way, while the rest seem to have no major problems. - In $95 \%$ of the cases interviewees admit that it is useful and convenient for the business a Corporate Governance framework.

- $30 \%$ of respondents say they do not know their percentage or share in the shares and, therefore, the value of their property.

- There is not much clarity (only 16\%) about the methods for estimating the value of the shares and the output model for those who have decided to switch off.

- Only $23 \%$ of those interviewed agree to follow a clear or well-designed strategy and to be able to measure results. To say that this is partially taken (44\% of the sample), is to accept a serious content of improvisation. - $33 \%$ agree that it lacks a clear strategy, which in other words means that the business may go well, but may deviate from the stated goals. - Only $41 \%$ of companies surveyed state that their business processes are formalized and standardized (you can replicate them in another location). - Only $38 \%$ of those responsible assume that the organizational structure is clear, and that management positions and responsibilities are well identified. - In $61 \%$ of the sample, the contribution of workers is not clearly identified or valued, and for them there are no formal mechanisms of retention (of staff).

The strategy to take the business forward
- In contrast, family members are often not evaluated and compensated for their abilities and results (78\% of the sample), revealing an unfair and uneven picture.

- $38 \%$ of respondents say they have projections and budgets, supported by a business case.

- $72 \%$ of the sample ensures that they do not have the habit or practice of following up budgets and business plans.

- Only $32 \%$ of entrepreneurs have indicators for critical business issues and to document their performance.

- $42 \%$ of the entrepreneurs interviewed admit that their businesses are still fragile and that their operation depends on one or two people.

- Entrepreneurs were asked about their experiences in requesting some type of credit or financing, and majority responses (49\%) go in the sense that they have had no objections. In contrast, $32 \%$ acknowledge that they have had some kind of difficulty or complication.

Source: own elaboration (2017), based on KPMG México (2013: 11-33). 
Another interesting figure pointed out by KPMG (2013: 35) is that family businesses generate more than $90 \%$ of the Gross Domestic Product (GDP), and are involved in all industrial, trade and services. That is why they are vital for the economic development of the country.

\section{Social Economy}

According to the National Institute of Social Economy (INAES) (2014a), the social economy originates in the workers' association of the nineteenth century, facing the poor living conditions, exploitation of workers, lack of employment and migration to the cities that generated the first Industrial Revolution. Given these situations of precariousness and suffering, the workers were organized and the first cooperatives and mutual societies of the modern era were born.

One of the primordial elements of the social economy is the cooperativism and the principles that regulate the cooperatives; to this day, these principles are governed by those established by the Rochdale Cooperative of England (1844), which were adopted by the International Cooperative Alliance (1895).

In 1989, the term social economy was coined, at the time, by the Commission of the European Communities. Morgado (2006), proposes a definition as follows

A company belongs to the social economy if its productive activity is based on specific organizational techniques These techniques are based on the principles of solidarity and participation (which normally responds to the norm: one man, one vote) among its members, being the producers, users or consumers, as well as values of autonomy and citizenship. In general, these companies adopt the legal form of cooperative, mutual or association (p. 35).

Another author, Hernández (1994), points out that such a term can be understood as a set of organizations and companies with similar sociological, economic and operational characteristics that seek to solve economic problems of broad social groups.

In this sense, Altschuler (2008) points out that the main objective of the social economy is the generation of sources of labor and income, the distribution of benefits and surpluses, the satisfaction of individual and collective needs, aimed at improving the quality of life of the population. Having as premises, greater environmental sustainability; cultural sustainability, as processes based on the identity of the population and the territory: political sustainability, that is, the legitimacy of democratic processes in decision-making; and social sustainability, based on the idea of inclusion, through cooperatives and mutual associations, associations of small producers, barter clubs and popular fairs, factories recovered or self-managed, productive projects, community and mutual aid of movements of unemployed or social organizations.

So, Social Economy can be a strategy that involves a new form of collective action and organization of labor relations and production. Both in the traditional side of the cooperatives and mutual associations as in the experiences of the enterprises of the new social economy. (Altschuler, 2008).

In Mexico, more than 61,717 organisms of the social sector of the economy in the country are registered. Half of these are commons (29,555), 2359 are communities and 15,000 are cooperative societies (INAES $\left.{ }^{2}, 2014\right)$.

The Consultative Committee of the European Commission of Cooperatives, Mutualities, Associations and Foundations (CMAF) (1999, quoted by Morgado, 2006) established the common characteristics of all the organizations of the Social Economy, which distinguish them from Capital Corporations:

-Primacy of man and social objective over capital; With the exception of foundations, are all companies of persons.

-Voluntary and open membership and democratic control by its members from the grassroots.

-Conjunction of interests of the members, users and / or of general interest.

-Defense and application of the principle of solidarity and responsibility.

-Autonomy of management and independence of public powers.

\footnotetext{
${ }^{2}$ Instituto Nacional de Economía Social
} 
-Application of the surplus to the social object through reinvestment or distribution according to the wishes of its members to create jobs, activities, new businesses, return on invested capital, service to members, socio-cultural activities, and so on (p. 38).

However, Hernández (1994) describes, based on the criteria used by Conseil Wallon de L'Economie Social, the following requirements, for a company to be included as part of the social economy:

-When the purpose of the companies is to serve their members or the environment where they carry out their activity. (Social interest predominates over the particular). According to this requirement, social economy enterprises are an end in themselves and not a means or instrument. The purpose is constituted by the activity they perform and not by the benefit or power they can obtain or pursue.

-If there exists within it a management autonomy. This requirement forms the basis of the associative dynamic that makes it possible to differentiate the social economy from other productive sectors.

-The processes of decision-making must be democratic, using as criteria the individual and not the capital that is owned, the person's premium and work on capital in the adoption of decisions. The profit is awarded not to capital, but is distributed in a social way.

Thus, it is argued that, in social economy enterprises, relations between partners, based on the principles of equality and solidarity, are gaining importance in the face of the economic and profit-increasing goals that prevail in capitalist enterprises (Morgado, 2006).

Being said that, the cooperative society emerges as an alternative of the social economy whose central axis is the union of efforts between the partners; relatives, neighbors, friends, and so on, to seek social and work well-being, where their interests, through the cooperative philosophy, are "willing to share their insights because they had a stake in the results and believed that their input would be influential. They trusted that the outcome would be beneficial to them" (Reynolds, 2013 p.6).

For the International Organization of Cooperatives in Industry and Services (2017), the cooperative is an autonomous association of persons voluntarily united to meet their common economic, social and cultural needs and aspirations, through a jointly and democratically owned enterprise control. As Reynolds (2013) stated some of the cooperative features:

People will accept major changes if they feel they have been able to influence the decision. Although this isn't a universal trait, members who value democratic control of the cooperative are more likely to have a positive attitude toward the firm (p. 6).

The cooperative and the family business share this common feature of being more open to the participation in the process of decision making and that it is very clear in this particular case, where the implications for the social economy can be more important due its relation with the future development of this business model and the wellbeing of future generations.

\section{Results}

The "El Maviri Cooperative Tourist Services Society" is part of one of the four cooperatives of this route that are located in the bay and port of Topolobampo, which allows the connection of businesses in the north-west of Mexico (Integral Port Administration of Topolobampo, n.d.), as it is located in the state of Sinaloa, on the coast of the Pacific Ocean 200 miles from the entrance to the Gulf of California. The port is connected by railroad, a 4-lane highway and an international airport.

In this scenario is located the family business organized as a cooperative of tourist services. Armando PinzónRojo, member of the cooperative, mentioned some of the story of the cooperative, which started 35 years ago in 1985 with his father, Mr. Ramón Pinzón López who originally had an occupation as a fisherman, he was a "restless and visionary man" in need of work to support his family, formed by his wife Mrs. Adelina Rojo and the offspring of 10 children, two women and eight men; in addition to his appreciation for the Bay and Port of Topolobampo he envisioned the tourism potential of this place.

Mr. Ramón Pinzón López, who has already died, left this legacy to his children, including only his boys to continue with the operation of the business but leaving aside the women of the family. This discrimination is seen by the family as "normal" because they think women just can't do this kind of work. 
The Pinzon's business was the first tourist cooperative in Topolobampo, based on the El Maviri Beach, where they began giving its services, first with boat rides, later in banana boats, and little by little as years pass they grow as a company as wellas the need for more services likesport fishing and tours around the bay for the tourists, for these activities they had acquired 14 boats, one for each son, although some of them have two.

Figure 2.- The Pinzón Family.

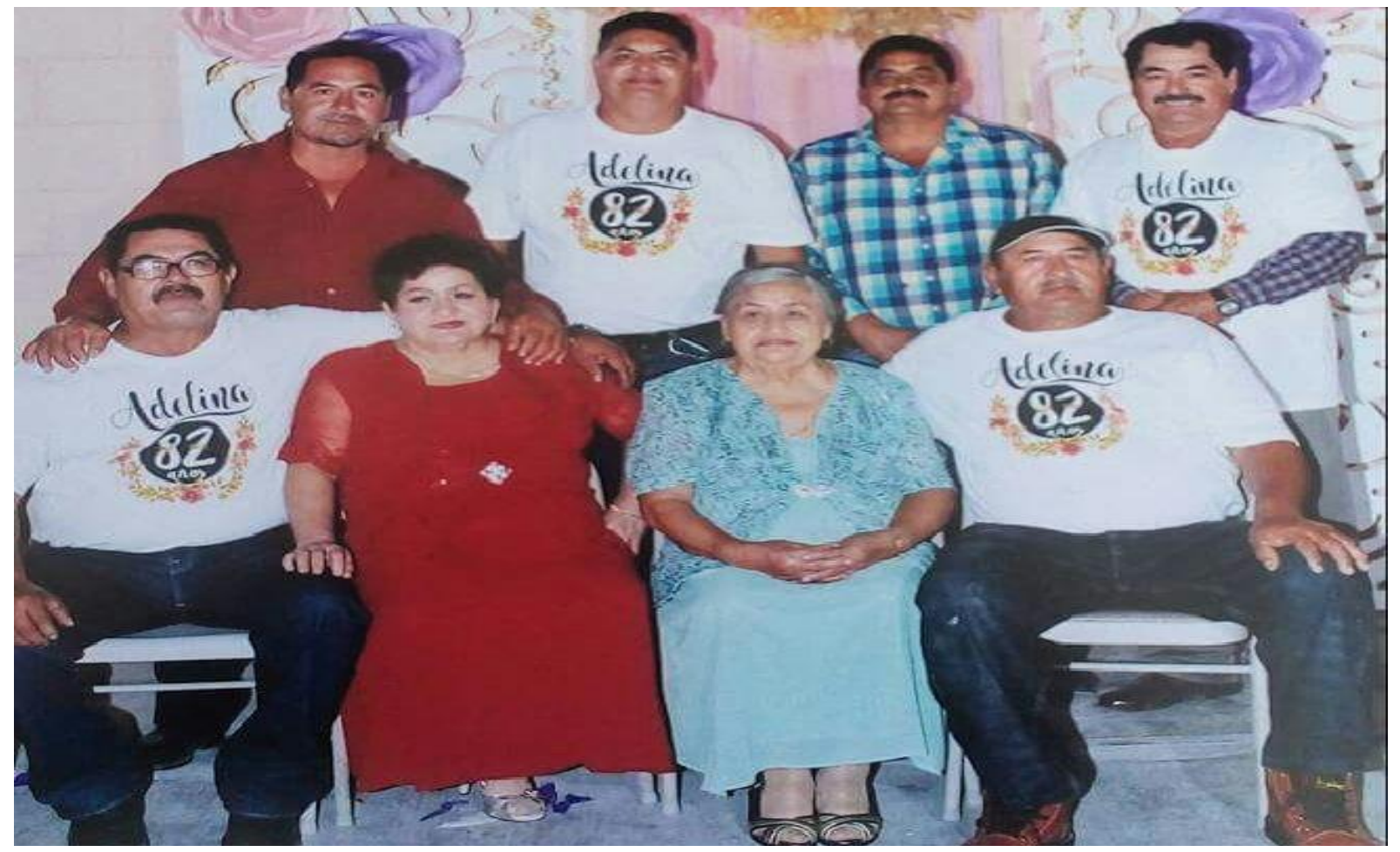

Source: Pinzon Family’s photograph archives.

As time went by the cooperative had to change its location to the Topolobampo seawall because on the beach, the tide goes down and they had to push the boat towards the sea and the tourist gets wet when climbing to the boat and on the boardwalk, it is easier to access; they already have eight years providing the service there, with 15 members of the family. It is worth mentioning that they are also engaged in fishing as a complementary economic activity as tourism is seasonal in this region.

Later four of the children emigrated to the state of Baja California, went to fish for shrimp and in time they decided to stay there and now reside in San Carlos, a small fishing community where, according to their statements it is more profitable for them. Only when they return for vacation they work in the tourist service.

The official name of registration of this company is "Sociedad Cooperativa de ServiciosTuristicos El Maviri Beach S.C.L.", however the grandchildren of the founder use a shorter and more commercial name for marketing and for social networks: "Torbellino'sTopolobampo Tours", Tourism Agency with guided tours by The Bay of Topolobampo. The members of the family cooperative are known with the nickname of "Los Torbellinos" or "Los Pinzones",that dates back more than 50 years; this come back to the founder of the cooperative, who in those years working as a fisherman, transported the guano in long boats, and the crew of a large ship called "Torbellino", asked Don Ramón Pinzón to bring them some supplies, so the captain of that ship told Don Ramón that he was going to give him paint for his boat (because on those days It was very difficult to obtain it), but he asked him to changed its name to"Torbellino" like his, so since then each boat of the Pinzón family was marked with the name of "Torbellino" I, II, III, and so on.

The family had a major boom 20 years ago, when they acquired a plot of land on El Maviri Beach, which at first, they considered it to build the cooperative's offices there, as it is at the edge of the beach, make a dock and give their services, but the brothers started to emigrate from the port and that was not achieved. Mr. Armando Pinzón, said that 
"the tourist activity is slowly growing", but there is a "lack of infrastructure", he points out that there is a hotel in the town but tourists prefer to stay in Los Mochis city, $23 \mathrm{~km}$ away.

Now there are three brothers in charge and they are planning to incorporate their children; there are 4 boats that the cooperative operates administrated by this three brothers and their children, one of them is a lawyer, Armando Pinzón, and grandson, Ulises Pinzón son of Armando, is in his third year in the law school, he said that he "likes the activity", and according to his father "is a young man with determination, character and attitude of service, with a care towards the excellent treatment to the tourist". Ulises has two other brothers who studied engineering in Tijuana, Mexico and live there and work in their area.

In this context, family members continue to work within the legal framework of the cooperative, with regular permits, boats with safety conditions for the tourist, such as lifejackets, comfortable seats, radio communications, preventive lights, etc. The following services:

1. Tour in the bay: it has a duration of 1 hour, is a tour along the shore to observe the facilities of the bay, the various ships that dock at their respective docks, birds and main, large groups of dolphins which are observed to interact between the boat.

2. Tour to the birds' sanctuary: it lasts approximately 1 hour 20 minutes, this tour consists of visiting the sanctuary of birds or also known as island of the ducks, an island that has the peculiarity that there are always different types of birds posing and others overflying, with a lot of migratory birds in winter.

3. Tour to see the "pechocho" dolphin: it lasts approximately 1 hour 40 minutes, visiting the friendly and unique dolphin that approaches the boat to play with the visitors, this is the number one attraction of the bay.

4. Recreational fishing: rent of the boat per hour to practice recreational fishing in the bay.

5. Tour to the beaches: It is a visit to Hamacas, Las Copas, Santa Maria andEl Maviri beaches each one with unique qualities.

6. Whole day boat rental: it is a proactive activity which includes the bird sanctuary, the dolphins in the bay, fishing, a visit to the beach.

Armando and his son Ulises share the vision of going further in providing the Tourist Services, in the sense of not only waiting for the tourist to come to the bay to offer the tours, but to go to the city of Los Mochis, and seek for the local, regional and international tourist, promoting and publicizing what the cooperative can provide them. They are planning to become independent, Mr. Armando intends to acquire a larger boat, and offer to the tourist a special service of all day tour that includes visits to all the sites of the bay, the sanctuary of birds, the dolphins and the famous dolphin "pechocho", offer fishing activities for the tourist and even prepare the fish caught in ceviche or fish tacos. They want to offer "unique experiences" that could also rescue the importance and the impulse of the social economy of this organizational form

This cooperative as a family business, summarizes some the theories presented before in the document (Casillas, et al, 2014, Belausteguigoitia, 2012) as it is evident that they have been in a process of weakening and possibly disappearance in the near future. According to the interviews and the observation made it is clear that the second generation of the business is controlled by three of the founder's sons: Manuel, 64, Armando de 50 and Rubén de 47 who are willing, except for Armando, to continue this business the same way it was managed for their father. A member of the third generation, Ulises son of Armando,has convinced his father to forget about the concept of the cooperative and move to form a conventional family business that can be "stronger and more profitable". Ulises argues that this way they can assure the family legacy but other members of the family, according to he interviews, see this as a threat because they will lose the control of the business and they could end as employees and not owners anymore.

Most of the members of the cooperative believes that there is no reason to change anything in the business model, they want "equal profits for everybody", and a "democratic way to choose their leaders". They don't believe that giving power to one person only to manage the business is a good idea, they stated that they are "owners" not "employees" and there is have to be another way to grow with mutual benefits and responsibilities. This reflects

On the other hand, the opinion of Ulises Pinzónis that from his perspective, the port has a great commercial development, as well as has a great tourist potential that is not exploited or giving the publicity deserved, he emphasizes that they need to be more "innovative" and move forward, that the cooperative it is becoming obsolete as a business model. He is in college studying, and this could explain all this new set of ideas that are confronting 
the old and traditional way of doing business among the members of his family. He fears that the business could collapse in the future and wants a change to benefit "everyone not only me and my father" he said.

About Topolabampo Ulises stated that "It is a baywith many qualities; It's very quiet, it is perfect to do the tours without any risk". The young man comments in reference to the Playas El Maviri Cooperative: "I am very proud to be part of this family business, something that started from my grandfather and I as a third generation have the opportunity to continue but we need to change, we need to be more efficient and have more control of our economic resources and profits. I consider the tours a fantastic activity to provide a service that show visitors the majesty of our port. Many times, they ask me if I do not get bored because it is always the same route, to which I answer a blunt no, since each tour is incomparable, they are different people and each one enjoys this experience in a different, very unique way".

\section{Conclusions}

Family businesses carry out various tasks in the community where they are inserted, generating a social and economic impact through the activities they develop, as well as contributing to the solidarity, mutual support, fellowship, values and ethics among the family.

On the other hand, the social economy is manifested by the well-being and the conception of productivity and competitiveness in the community itself, being a perfect space for the family business, which encourage the collaborative work with the aim of sustaining the company in future generations bringing more benefits for its members and the community itself.

In this community, the tourist activity has been also an important factor for the development of the social economybecause many businesses that offer diverse products and services, such as restaurants, ice cream shops, cafeterias, bars, public restrooms and parking as well as other cooperatives are benefited from it. This activity also allows the commons authorities to manage resources to implement improvements in the community, attend state and federal projects to get resources for the welfare of the community. That is why this cooperative is a clear example of the benefits and virtues of the social economy.

It was found that, in this particular case, the relationship of family business and social economy is a space to grow, develop and consolidate the project to strengthen a cooperative that emerged in the family and for more than 35 years has remained, overcoming consanguineous crises until today, reaching the third generation.

The cooperative has preserved the philosophy of mutual aid, solidarity, and contribute to the promotion of the social economy, through its active participation in the image of the port, order and discipline in its work, in the development of sustainable actions such as the collection of garbage and the use of ecological engine in their boats, which reflects the character of self-management and self-awareness of their social responsibility.However,this could change if there is a rupture among the members of the cooperative. It is evident that they are going through a generational battle of ideas about how to manage the business and even about the business model they want in the future.

The results show that the family cooperative operates by tradition and legacy of the initiator, and is a mean to obtain profits to meet the basic needs of families. However, the family envisages a transition from cooperative to family business, this because of the entrepreneurial nature of some of its members, as well as the level of commitment to the locality.

This controversy among the members who wants to keep the current status quoof the business and the ones who want a different kind of management could condemn this business to an eternal impasse that literally could tear apart the cooperative. It is clear that there is a fight for the control of the business and the new generation do not want to follow the path of the founder with all his ideas of solidarity, mutual responsibility and equal benefits for all members. In this scenario, the older members of the family want to keep the cooperative the way it is, fearing any future changes to their position.

Nevertheless, it can be concluded that there is a social and economic impulse of the El Maviri Beach Cooperative by attracting tourists to the port of Topolobampo, creating the conditions for the development and improvement of the quality of life of several family groups established in the community, as well as proposing a permanent collaboration model that can support the decision-making, its structure improvement, the environmental responsibility and selfmanagement; always encouraging a democratic and participative environment. 


\section{References:}

[1] Administración Portuaria Integral del Topolobampo, (n.d.). Puerto de Topolobampo. Secretaría de Comunicaciones y Transportes. Gobierno Federal. México.

[2] Altschuler, B. (2008). Repensando el desarrollo: aportes y limitaciones del desarrollo local y la economía social a una estrategia de desarrollo. In L. Martínez Valle, Territorios en mutación: repensando el desarrollo desde lo local (1 ed.) (p. 29-45). Quito: FLACSO Ecuador.

[3] Belausteguigoitia Rius, I. (2012). Empresas familiares: dinámica, equilibrio y consolidación (3 ed.). México: Mc Graw-Hill/Interamericana.

[4] Casillas, J. C., Rus, S., Díaz, C., \& Vázquez, A. (2014). Gestión de la empresa familiar: conceptos, casos y soluciones (2 ed.). España: Paraninfo.

[5] Ginebra, J. (1997). Las empresas familiares: su dirección y su continuidad (1 ed.). México: Panorama editorial.

[6] Gómez-Betancourt, G. (2005). ¿Son iguales todas las empresas familiares?: caminos por recorrer. Bogotá: Grupo editorial Norma.

[7] Hernández Perlines, F. (1994). Estructura y resultados de la economía social en Castilla-La Mancha: rasgos diferenciadores. Murcia: Universidad de Castilla-La Mancha.

[8] Instituto Nacional de la Economía Social. (2014a). El ABC de la Economía Social. Retrievedon 02/25/2017, fromGob.mx:https://www.gob.mx/cms/uploads/attachment/file/102028/ABC_de_la_Econom_a_Social_e_INAES.pdf

[9] Instituto Nacional de la Economía Social. (2014b). Nociones Básicas de la Economía social. Retrieved on 02/25/2017, from Gob.mx: http://www.inaes.gob.mx/doctos/Nociones1\%20x\%20web/index.html

[10] KPMG México. (2013). Empresas familiares en México: El desafío de crecer, madurar y permanecer. México.

[11] Leach, P. (1999). La empresa familiar. Granica.

[12] Meira Teixeira, Rivanda \& Carvalhal, Felipe (2013). Sucesión y conflictos en empresas familiares. Estudio de casos múltiples en pequeñas empresas hoteleras. Estudios y Perspectivas en Turismo, vol. 22, núm. 5, 2013, pp. 854-874. Centro de Investigaciones y Estudios Turístico.

[13] Morgado Panadero, P. (2006). La economía social y su marco Legal. In P. Morgado Panadero, \& L. Burgos Rosado, Economía social y cooperativismo (págs. 34-45). España: Lex Nova.

[14] Neubauer, F., \& Lank, A. G. (2003). La empresa familiar: cómo dirigirla para que perdure. España: Deusto.

[15] Organización Internacional de las cooperativas en la industria y los servicios (2017). ¿Qué es una cooperativa? Retrieved on 02/25/2017, from: http://www.cicopa.coop/Que-es-una-cooperativa.html

[16] Reynolds, A. (2013). Defining the value of the cooperative business model: an introduction. CHS Center for cooperative growth, dostupno na: internetska stranica. Retrieved on 07/23/2017 from: http://www. uwcc. wisc. edu/pdf/Reynolds_WhitePaper_values.pdf. 